\title{
Exotic introductions to the fishery of Lake Victoria: What are the management options?
}

\author{
M. Njiru, ${ }^{1 *}$ E. Waithaka, ${ }^{1}$ M. Muchiri, ${ }^{2}$ M. van Knaap ${ }^{3}$ and I. G. Cowx ${ }^{4}$ \\ ${ }^{1}$ Kenya Marine and Fisheries Research Institute, Kisumu, Kenya, ${ }^{2}$ Fisheries Department, Moi University, Eldoret, Kenya, \\ ${ }^{3}$ W6703 Wageningen, the Netherlands, and ${ }^{4}$ University of Hull International Fisheries Institute, University of Hull, \\ United Kingdom
}

\begin{abstract}
Lake Victoria is Africa's most important source of inland fishery production, exhibiting annual catches of $\approx 400000 \mathrm{mt}$. The predatory Nile perch, Lates niloticus, and the herbivorous tilapiines, Oreochromis niloticus, Oreochromis leucostictus, Tilapia zillii and Tilapia rendalii, were introduced in Lake Victoria in the 1950s and 1960s. Nile perch were introduced to convert the abundant, but bony, haplochromines to fish flesh, while the tilapiines were introduced to boost the declining fishery. Since that time, the fisheries of Lake Victoria have undergone dramatic social and ecological changes. The catches increased tremendously, changing the fishery from artisanal to commercial, in turn increasing fisher income and employment opportunities. However, there was a decline and, in some cases, the disappearance of many indigenous fish species, especially the haplochromine cichlids. This reduction was attributed to overexploitation, predation, and competition and hybridization with the introduced species. The decline of the native fish species has had impacts on the trophic and ecological status of the lake. Nile perch now dominate the formerly complex food web. The loss of phytoplanktivorous haplochromines has contributed to an increase in algal blooms, reduction in water quality and occasional fish kills. Water hyacinth, Eichhornia crassipes, invaded Lake Victoria in 1988, with high rates of infestation in shallow waters and bays, which are breeding and nursery grounds for most fish species. Catches of Nile perch decreased following the infestation, while those of Nile tilapia, lung fish (Protopterus aethiopicus) and mud fish (Clarias gariepinus) increased. Haplochromines species also showed some signs of recovery. In view of all these changes, the future of the Lake Victoria fishery is uncertain.
\end{abstract}

\section{Key words}

exotic introductions, fisheries management, haplochromines, Lake Victoria, Lates, overfishing, tilapiines.

\section{INTRODUCTION}

Lake Victoria is the second largest lake in the world by surface area, covering $68000 \mathrm{~km}^{2}$ in East Africa (Fig. 1). It has a mean depth of $40 \mathrm{~m}$ and a shoreline of $\approx 3500 \mathrm{~km}$, which is shared by the bordering states of Kenya (6\%), Uganda (45\%) and Tanzania (49\%). The lake is an important source of food, employment and earnings for the riparian communities through the exploitation of fish resources.

The species composition of the catches in Lake Victoria has changed from those which prevailed at the beginning of the 20th century, when the fisheries development started (Ogutu-Ohwayo 1990; Othina \& Tweddle 1999). Until the 1970s, the tilapiine species Oreochromis esculentus (Graham)

*Corresponding author. Email: rmnjiru2002@yahoo.com

Accepted for publication 18 May 2005. and Oreochromis variabilis (Boulenger) were the most important commercial species. Other important species included Protopterus aethiopicus (Heckel), Bagrus docmak (Forskåll), Clarias gariepinus (Burchell), various Barbus species, mormyrids and Schilbe intermedius (Rüppell). Labeo victorianus (Boulenger) formed the most important commercial species in the affluent rivers of the Lake Victoria basin. Haplochromine cichlids and a native cyprinid, Rastrineobola argentea (Pellegrin), were abundant, but were not originally exploited on a large scale because of their small size (Kudhogania \& Cordone 1974; Ogutu-Ohwayo 1990).

Four tilapiine species, Oreochromis niloticus (L), Oreochromis leucostictus (Trewavas), Tilapia zillii (Gervais) and Tilapia rendalii (Boulenger), were introduced into Lake Victoria in the 1950s and 1960s to increase catches, which had declined due to overfishing (Ogutu-Ohwayo 1990). Nile 
perch were also introduced about the same time to convert the bony and small, but abundant, haplochromines to suitable table fish. The contribution of haplochromines to fish biomass decreased rapidly, from $83 \%$ during the 1970 s to $<1 \%$ by the mid-1980s. The Lake Victoria fishery currently is dominated by Lates niloticus (60\%), R. argentea (30\%) and O. niloticus (7\%) (Othina \& Tweddle 1999; Cowx et al. 2003).

In addition to exotic fish introductions, water hyacinth, Eichhornia crassipes (Mart.) Solms-Lauc, invaded Lake Victoria in 1988 (Muli et al. 2000). The rapid expansion of densely compacted mats covered the lake, with severe economic, social, health and environmental impacts. However, the aquatic plant also facilitated the recovery of some indigenous species, such as mud fish (Clarias spp.) and lungfish (P. aethiopicus) (Njiru et al. 2002).

Taken at their face value, the benefits of transforming the fishery of Lake Victoria from artisanal to commercial by exotic introductions would appear to be substantial (Abila 2000). However, the negative impacts of development are even more compelling. This paper explores the impact of introductions to the fishery of Lake Victoria and outlines possible management strategies.

\section{CATCH TRENDS}

There has been a rapid increase in catches in Lake Victoria since the mid-1980s (Fig. 2; Cowx et al. 2003). The annual catches in Kenyan waters increased from $19000 \mathrm{t}$ in 1976 to $\approx 220000 \mathrm{t}$ in 1992 , declining thereafter to $152000 \mathrm{t}$ in 2001. In Ugandan waters, the total fishery yield increased from $11000 \mathrm{t}$ in 1977 to $120000 \mathrm{t}$ in the early 1990s. Data are fragmented in the 1990s and no trends are discernible, except that fish landings in the year 2000 were of the order of $175000 \mathrm{t}$. In Tanzanian waters, the quantity of fish landed increased from $72000 \mathrm{t}$ in 1983 to $231000 \mathrm{t}$ in 1990 . Poor quality catch assessment data have prevented the identification of yield trends in recent years. Most of the catch increase in the three countries is attributed to Nile perch; however, since the mid-1990s, Nile perch have shown signs of decline throughout the lake (Othina \& Tweddle 1999; Cowx et al. 2003).

Besides Nile perch, introduced $O$. niloticus living in littoral and sublittoral waters also have increased since the

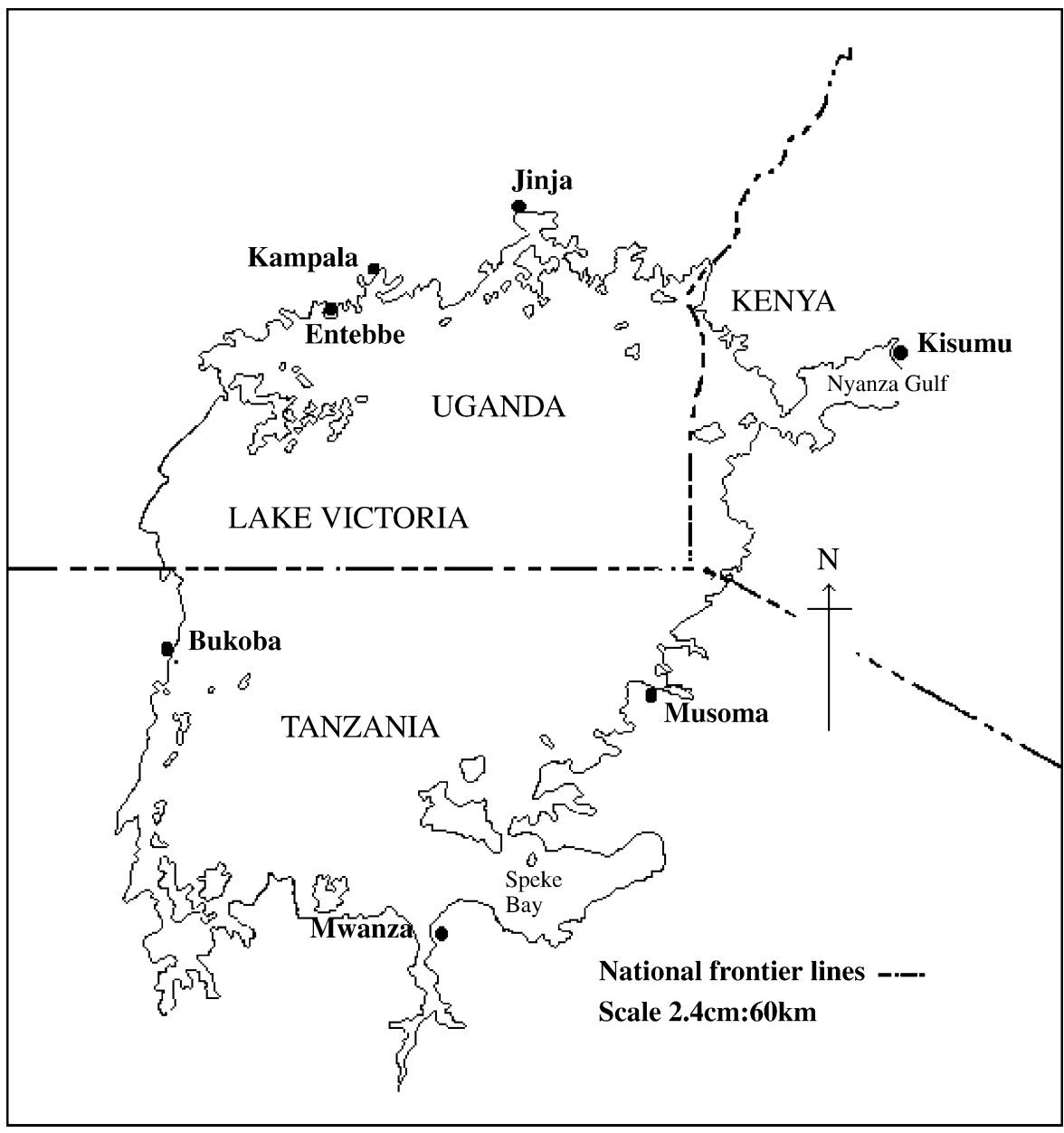

Fig. 1. Map of Lake Victoria, Kenya. 
middle of the 1980s in the Kenyan waters of Lake Victoria (Fig. 3). Nile tilapia is now the third most commercially important fish in Lake Victoria after Nile perch and $R$. argentea. Data from Uganda and Tanzania are either lacking or fragmented, making it impossible to discern any trends for these countries.

To maintain production, efficient fishing methods and increased fishing effort have resulted in overexploitation and the capture of immature fish, threatening the existence of the whole fishery. For example, most Nile perch are caught below $5 \%\left(\mathrm{Lm}_{50}\right)$ maturity. The Nile perch $\mathrm{Lm}_{50}$ is between 55 and $64 \mathrm{~cm}$ TL for males and 73-78 cm TL for females (Fig. 4). The capture of immature Nile perch is attributed to processing factories. The factories around the lake have a capacity to process Nile perch that far exceeds the quantity of fish they are able to obtain (Abila 2000). Previously, the factories only processed Nile perch with a minimum weight of $2-3 \mathrm{~kg}$. As a result of increased competition for wet fish, however, the plants now accept lower weight fish, at times as low as $1 \mathrm{~kg}$. Some factories also have started to fillet tilapia in addition to Nile perch (Abila 2000).

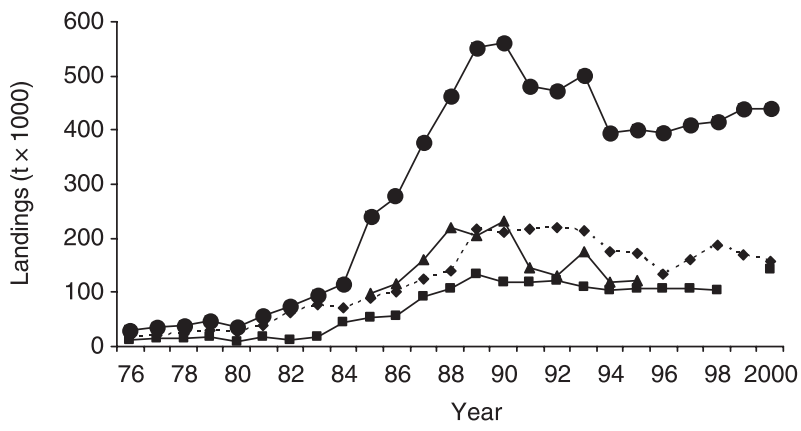

Fig. 2. Trends in total fish landings ( $\mathrm{t}$ ) in the riparian areas of Lake Victoria. $\bullet$, Kenya; $\mathbf{\square}$, Uganda; $\boldsymbol{\Delta}$, Tanzania; $\bullet$, total.

\section{SOCIAL AND CULTURAL ASPECTS OF FISHERIES}

The Nile perch fishery created a remarkable economic benefit, which expanded the artisanal fishing industry to a multimillion-dollar export industry for Nile fillets. In terms of income, it is estimated that a Kenyan fisher earns
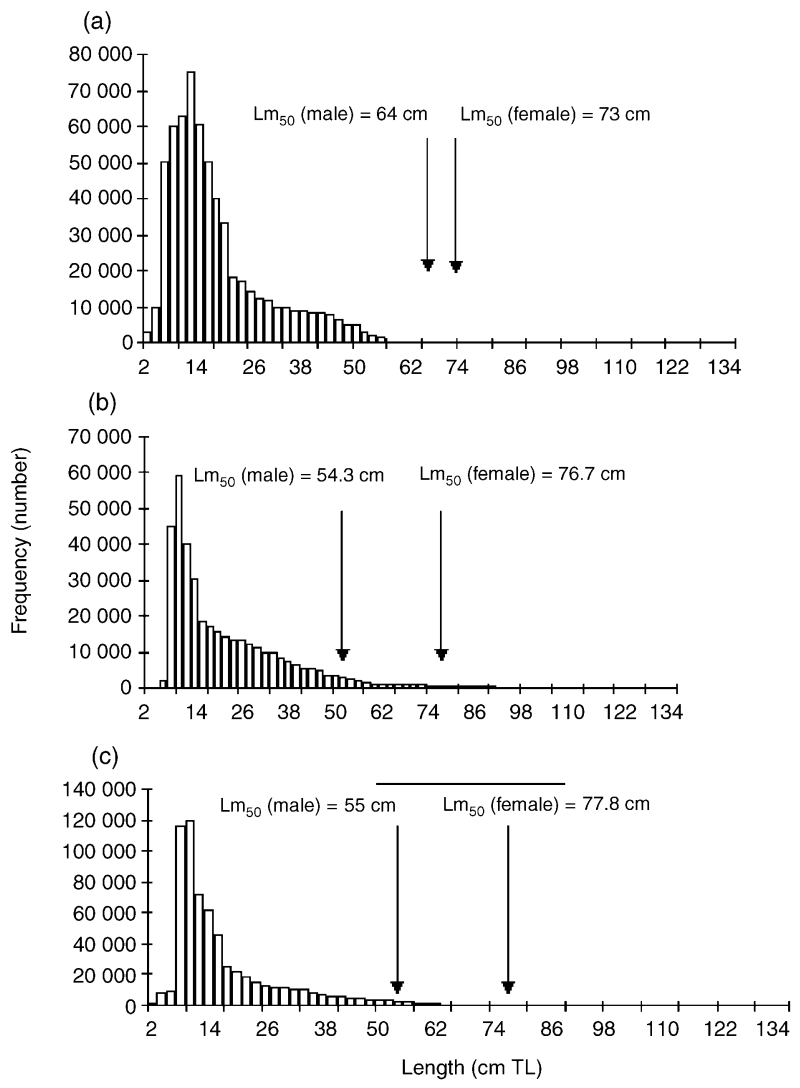

Fig. 4. The length frequency distribution of Nile perch in trawl catches from Lake Victoria. (a) Uganda, (b) Tanzania, and (c) Kenya. The arrows indicate the length at 50\% maturity $\left(\mathrm{Lm}_{50}\right)$ and the bar in (c) indicates the recommended slot size $(50-85 \mathrm{~cm} \mathrm{TL})$; adapted from Cowx 2001.

Fig. 3. Annual catches of haplochromines, tilapiines and other species (mainly Clarias, Protopterus) in Lake Victoria. -, Tilapia; $\times$, haplochromines; ---, others.

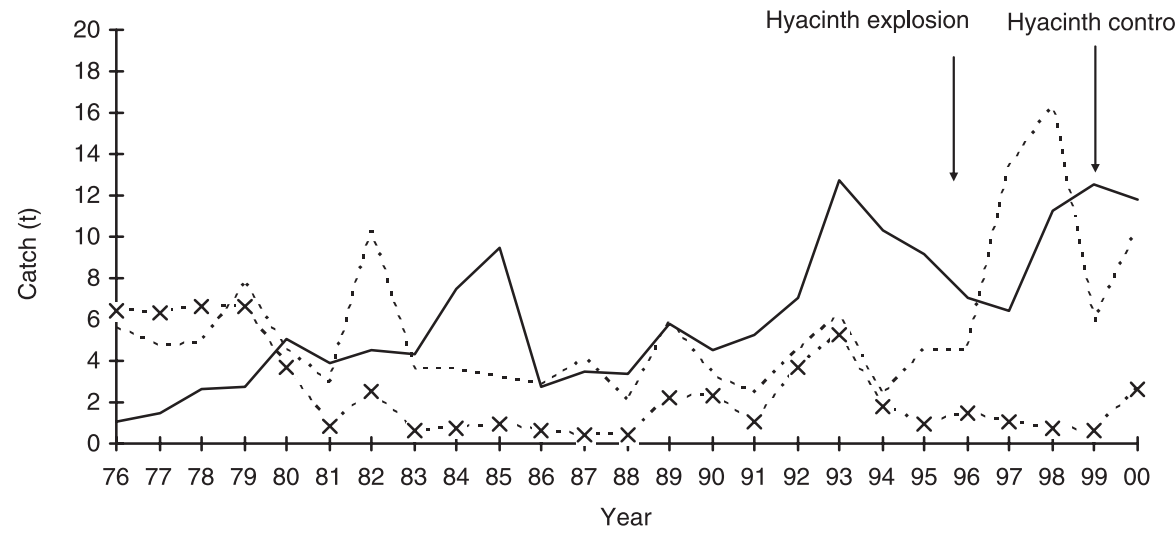


\$US3300 year ${ }^{-1}$, while in Tanzania, a fisher earns $\$$ US2300 year $^{-1}$ and in Uganda, a fisher earns \$US1157 year ${ }^{-1}$ (SocioEconomic Data Working Group 1999). In 1994, the revenue from fish landings in Uganda was $\$$ US77.13 $\times 10^{6}$, while in Kenya in 1998, the revenue from fish landings was $\$$ US80 $\times 10^{6}$ and in Tanzania, it was as much as \$US200 $\times 10^{6}$ during the same period (Socio-Economic Data Working Group 1999).

The Nile fishery boom involved the creation of many new jobs, especially in the processing industries. The numbers of fishers and their dependants rose in 10 years, from $\approx 480000$ to almost 1.3 million (Socio-Economic Data Working Group 1999; Witte et al. 1999). Compared to the pre-Nile perch era, the fisheries have improved the welfare of the lakeside communities. Currently, fish trading, processing and marketing has been dominated by large and medium-scale operators. The traders are able to access markets beyond the lake, making it possible to sell fish products throughout the East African region and in Europe, Asia and the United States of America.

In spite of the general economic boom, the changed Lake Victoria fishery has concentrated income among a smaller proportion of the participants in the fishery. In the pre-Nile perch period, small-scale operators dominated the fish processing and trading subsectors (Abila 2000). These were mainly women from the communities living around the lake. They sold some fresh fish and processed the surplus, using such simple technologies as smoking, salting and sun-drying, for later sale. There were hardly any wholesalers or large processors. Local people have progressively been edged out of fish production by the pricing, marketing and processing advantages of the factories (Abila 2000). Fish factories and their agents tightly control these activities. Employment chances in traditional fish trading and processing sectors for Nile perch and its products, previously the preserve of poor women, are now integrated in the marketing chain for fish processing and fish meal. A survey by Abila and Jensen (1997) found that six animal feed-manufacturing companies in Kenya were using $\approx 70 \%$ of the $R$. argentea that was produced annually to manufacture fish meal, while another two companies were using $60 \%$ of Nile perch skeletons produced for the same purpose. Only juvenile Nile perch or those rejected by the factories, plus surplus skeletons of Nile perch, remain behind as food for local communities. It is noteworthy that, until the late-1980s, all the Nile perch skeletons were used for human consumption and that, in the early 1990s, all the R. argentea was consumed by humans. This has implications for food security, employment, the living standards of the fishers and sustainable exploitation of the resources.

\section{DECLINE IN SPECIES COMPOSITION}

The decline in fish species in Lake Victoria is the largest documented loss of biodiversity caused by humans in an ecosystem (Witte et al. 1999). Until the 1970s, Lake Victoria supported a multispecies fishery dominated by the tilapiines O. esculentus and O. variabilis, and $>500$ species of haplochromine cichlids (Ogutu-Ohwayo 1990; Witte et al. 1999). The endemic cyprinid, $R$. argentea, was abundant, but not originally exploited on a large scale because of the small size. There also was an important subsidiary fishery for $>20$ genera of non-cichlids fishes, including $P$. aethiopicus, B. docmak, C. gariepinus, various Barbus species, mormyrids, S. intermedius and L. victorianus (Kudhogania \& Cordone 1974; Ogutu-Ohwayo 1990). It is believed that $>60 \%$ of Lake Victoria's endemic fish species became extinct between 1970 and 1986, with the remaining species reduced to insignificant levels (Fig. 5). The reduction in catches of the native species is attributed to predation by Nile perch and over-fishing (Witte et al. 1999).

To compensate for the decreasing catches of native tilapiines (O. variabilis, O. esculentus) in the $1950 \mathrm{~s}$, exotic tilapiines $(O$. niloticus, $O$. leucostictus, $T$. zillii, $T$. rendalii) were introduced into the lake, where they were expected to fill empty niches (Welcomme 1967). The indigenous tilapiines declined as a result of competition for food, spawning sites and nurseries, and the hybridization with the alien species (Welcomme 1967; Ogutu-Ohwayo 1990). Nile tilapia now dominate, whereas most of the other tilapiines are rarely caught in the lake.

\section{TROPHIC STATUS}

Before the introduction of Nile perch, Lake Victoria had an elaborate food web, with Clarias spp., B. docmak and

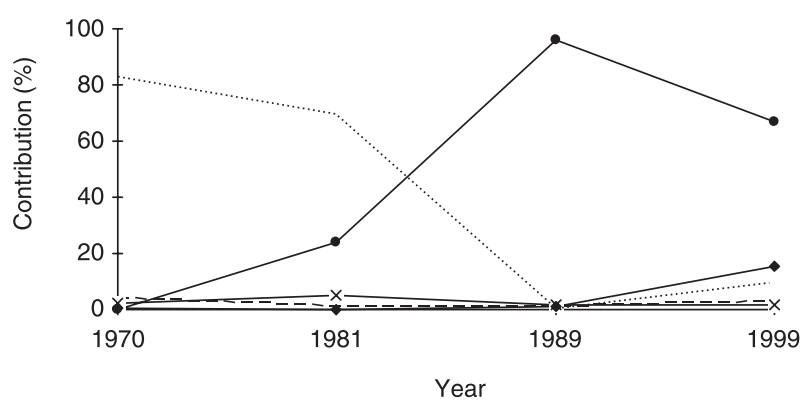

Fig. 5. The contribution of major commercial fish species in bottom trawl catches in the Kenyan waters of Lake Victoria. Sources of data: 1970, Kudhogania \& Cordone 1974; 1981, Okemwa 1981; 1989, Dache 1994; 1999, Getabu \& Nyaundi 1999. ‥, haplochromines; --- , Clarias; ×, Protopterus; Oreochromis niloticus;, Lates. 
P. aethiopicus as the major predators (Witte \& Densen 1995). With the upsurge of Nile perch, haplochromines and other fish groups, such as the catfishes, have decreased tremendously (Ogutu-Ohwayo 1990). In the 1970s, at least five trophic groups were common (Fig. 6; Witte et al. 1999). By the end of the 1980 s, detritivores/phytoplanktivores, once making up $>50 \%$ of the bottom-dwelling fish biomass, had mostly vanished. Current bottom trawl surveys show that the trophic diversity is again increasing in the lake (Getabu \& Nyaundi 1999). The increase in trophic diversity is attributed to changes in food resources in the lake (Njiru et al. 2004). The surface-dwelling haplochromines and zooplanktivorous/insectivorous haplochromines of the 1970s have been replaced by the pelagic cyprinid, $R$. argentea, which feeds on zooplankton and insect larvae (Witte $e t a l$. 1999). The increase in $R$. argentea is probably related to its higher fecundity, producing 20 -fold the numbers batch ${ }^{-1}$ compared with the zooplanktivorous haplochromines. After Nile perch became established in the lake, R. argentea showed a $50 \%$ decline in generation time and release competition after the destruction of the haplochromines (Wanink 1998).
Changes have been observed in invertebrate densities, with the most striking increase in the prawn, Caridina nilotica (Budeba 1999). The prawns became an important prey of the Nile perch after the decline of the haplochromines (Mkumbo \& Ligtvoet 1992). Recent trawl surveys showed a slight recovery of the haplochromines in the lake, which were mostly comprised of detritivores and phytoplanktivores (Getabu \& Nyaundi 1999; Witte et al. 1999).

\section{ECOLOGICAL CHANGES}

The water quality in Lake Victoria has declined greatly in the past few decades, due chiefly to eutrophication arising from the increased inflow of nutrients into the lake (Ochumba \& Kibaara 1989; Lung'ayia et al. 2000) and to changes in the fish community (Ogutu-Ohwayo 1990). The primary productivity has doubled and the algal biomass has increased 8-10-fold, accompanied by a shift in the algal species composition. The chlorophyll- $a$ concentration varies between 2 and $13 \mathrm{mg} \mathrm{m}^{-3}$ in the main lake and between 8.8 and $71 \mathrm{mg} \mathrm{m}^{-3}$ in the inshore waters (Lung'ayia et al. 2000), compared to $1.2-5.5 \mathrm{mg} \mathrm{m}^{-3}$ and $30 \mathrm{mg} \mathrm{m}^{-3}$ in the same waters in 1960 and 1961, respectively (Talling 1965). The (a)

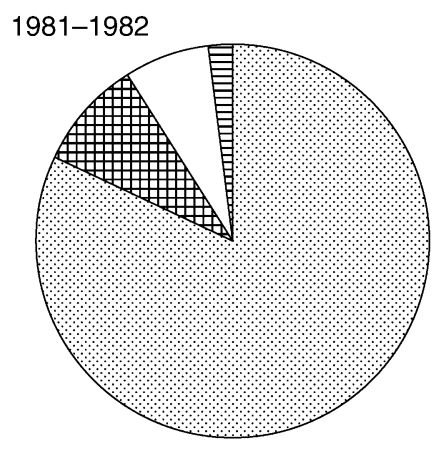

(d)

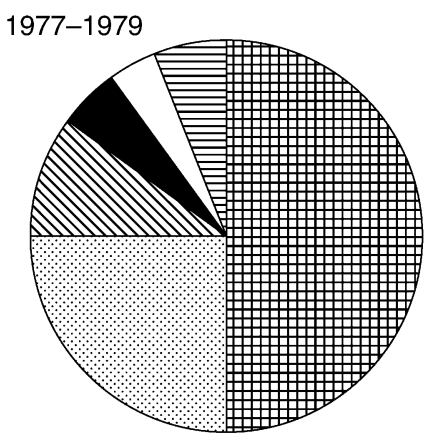

(b)

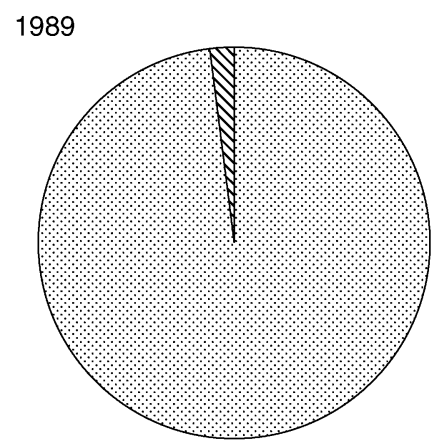

(e)

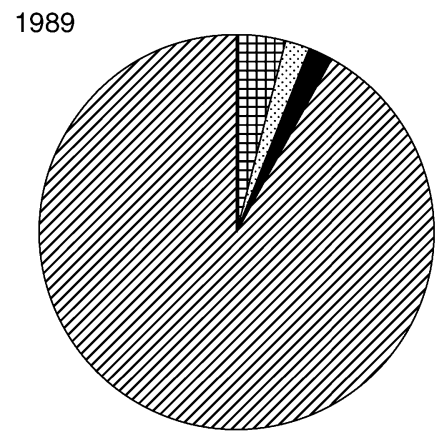

(c)

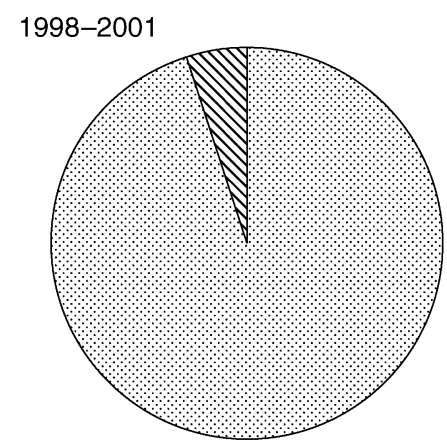

(f)

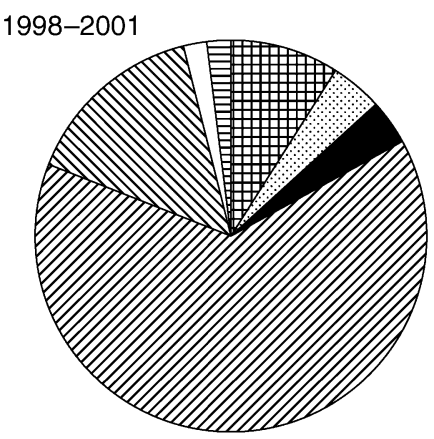

Fig. 6. The trophic composition of fish fauna in trawl surveys before and after Nile perch upsurges. (a)-(c) surface trawls, and (b)-(d) bottom trawls. Sources of data: 1977-1979, 1989 adapted from Witte et al. (1999). 曲, detritivore/phytoplanktivore; 8 , zooplanktivore;

, mollusc; $\llbracket$, prawn; $\mathbb{\mathbb { N }}$, insectivore; $\square$, piscivore; 目, rest. 
increase in chlorophyll- $a$ concentrations and the higher abundance of the buoyant cyanobacteria have resulted in decreased water transparency. The average transparency values (expressed as Secchi depth) have decreased from 7.3-7.9 $\mathrm{m}$ for offshore stations and 1.3-1.45 $\mathrm{m}$ in Nyanza Gulf in 1927 (Worthington 1930) to $1.1-1.38 \mathrm{~m}$ and 0.58$1.68 \mathrm{~m}$ in the same areas, respectively, during 1994-1995 (Lung'ayia et al. 2000). Massive blooms of algae, especially the toxic blue-greens, are now a common occurrence in the lake. Anoxic water attributed to the use of oxygen $\left(\mathrm{O}_{2}\right)$ by decaying flora in the lake is now spreading to the shallow water, causing occasional fish kills (Ochumba \& Kibaara 1989). Increases in hypoxia might reflect a combination of increased nutrient levels and losses of phytoplaktivorous/detritivorous haplochromine cichlids (Lung'ayia et al. 2000).

There has been an increase in hybridization among haplochromines, attributed to a decline in water quality. Laboratory studies have shown that females mate with other males when conspecific males are not available (Crapon de Caprona \& Fritzsch 1984). Decreases in water transparency since the 1970s have narrowed the light spectrum in Lake Victoria, changing the way female haplochromines perceive the colours of the males. The differences between species also can be masked. The reduced water clarity has caused a loss of genetic and ecological differentiation among haplochromine species and has contributed to the loss of species diversity among cichlids (Seehausen et al. 1997).

Increased nutrients in the lake could have contributed to the flourishing of the water hyacinth (E. crassipes), introduced to the lake in 1988 , which subsequently choked many bays and inlets and made fishing and navigation difficult (Muli et al. 2000; Niiru et al. 2002). Much of the water body covered by the hyacinth was rendered unfit for domestic use because of high organic and hydrogen sulphide concents. But, following the infestation of Lake Victoria by water hyacinths, catches of Nile perch decreased, while those of C. gariepinus, $P$. aethiopicus and Nile tilapia have increased dramatically, especially in hyacinth-covered areas (Figs 3 and 7) (Njiru et al. 2002). The extent of coverage by the water hyacinth has caused the deoxygenation of water and, at times, anoxic conditions in the water below the dense mats. The increase in C. gariepinus, P. aethiopicus and Nile tilapia catches was probably related to their ability to survive in low- $\mathrm{O}_{2}$ areas, reduced fishing pressure and predation by the perch, as well as increased food availability and breeding areas, especially in hyacinth-covered sites. The localized deoxygenation also could have played a role in the reduction in Nile perch, whose critical level of dissolved $\mathrm{O}_{2}$ is $5 \mathrm{mg} \mathrm{L}^{-1}$ (Wanink 1998). Tanzania and
Uganda, which had lower infestations at the same time, recorded fewer of these more tolerant species (Njiru et al. 2002).

\section{MANAGEMENT STRATEGIES The fishery}

The fishery of Lake Victoria is mainly in waters ranging from a depth of 0-25 $\mathrm{m}$ (Witte \& Densen 1995). There are $>40000$ boats, $>100000$ fishers with > 500000 assorted types of gear, utilizing the lake (Asila, unpubl. data, 2000). Although fishing efforts have been on the increase, the catch gear ${ }^{-1}$ has been on the decline (Niru et al. 2002). Studies of the lake have revealed that a majority of the fish are caught by illegal fishing methods or gear (Othina \& Tweddle 1999). To save the fishery from imminent collapse, a ban on illegal fishing methods and gear should be enforced. Licensing schemes and extension campaigns also should be established in anticipation of the need to restrict open access to the fisheries.

Probably the best solution to tackling the Lates menace is to try to better understand its biology and ecology in relationship to other species, with a view to maintaining the viability of the fishery. For example, a study conducted by Lake Victoria Fisheries Research Project from 19982001 recommended the capture of Nile perch of 50$85 \mathrm{~cm} \mathrm{TL}$ (Fig. 4) so that processing industries crop out

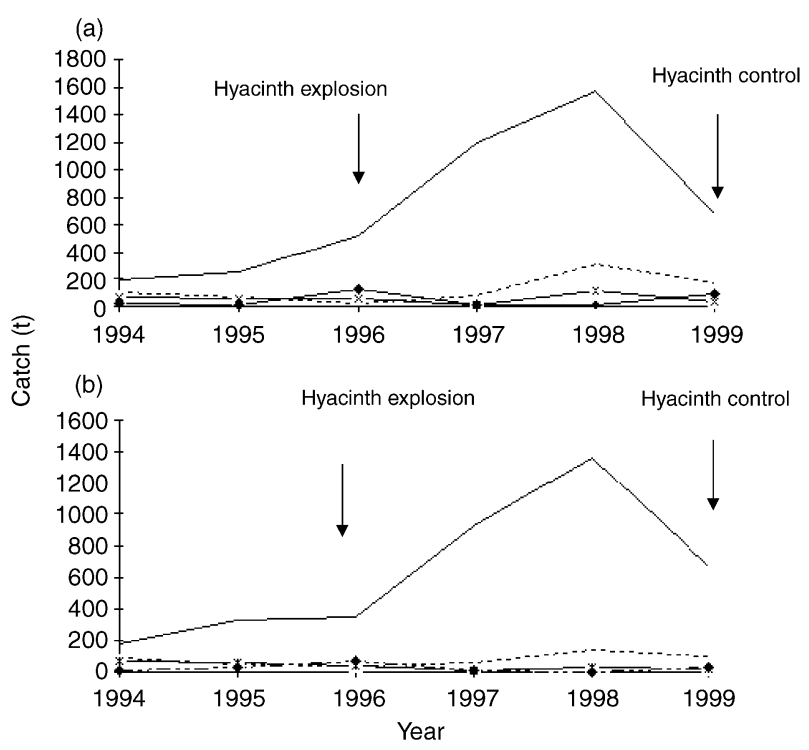

Fig. 7. The annual catches of (a) Clarias gariepinus and (b) Protopterus aethiopicus from different zones in the Kenyan Lake Victoria waters. Zones: - I: inshore shallow ( $<5 \mathrm{~m}$; sheltered); ----, II: inshore gulf (20 m, few sheltered bays); $x$, III and $\bullet, I V$ : offshore open waters ( $5 \mathrm{~m}$; shores exposed) (Njiru et al. 2002). 
only the mature fish (Cowx 2001). The advantage here is that Nile perch $\leq 50 \mathrm{~cm} \mathrm{TL}$ feed predominantly on C. nilotica, thus playing a beneficial role in converting invertebrates into fish flesh (Mkumbo \& Ligtvoet 1992). Larger fish ( $>50 \mathrm{~cm} \mathrm{TL})$ shift to a predominantly piscivorous diet comprised of $R$. argentea, juvenile Nile perch, Nile tilapia and haplochromines, which is both destructive to the lake's biodiversity and economically wasteful. Harvesting Nile perch $>50 \mathrm{~cm}$ TL could also lead to the recovery of the haplochromines, thus enhancing the productivity of the fisheries, especially in deep waters where only the pelagic $R$. argentea occur at present.

Vital information, such as good catch statistics, biological data and indices of distribution and abundance of commercial species, which are needed for defining management policies, are generally lacking in Lake Victoria (Cowx et al. 2003). In Kenya, for example, the fisheries department and the fisheries research institute have different catch statistics on the same fishery (Cowx et al. 2003). Thus, there is a need to harmonize data collection and continue with research to facilitate a better understanding of the fishery and to provide information upon which its rational exploitation and management can be based.

The supply of fish available to the local community within the lake basin is insufficient to meet demands. Aquaculture, which is poorly developed around Lake Victoria, could be a viable option for addressing this problem. In Kenya, for example, aquaculture contributes only $0.6 \%$ of the total landings, with the possibility of extra contributions being enormous.

\section{Policies and enforcement}

To date, the policies and regulations governing Lake Victoria's resources are different in each country (Ntiba et al. 2001). For example, the use of monofilament is banned in Tanzania and Kenya but allowed in Uganda. Fishing for $R$. argentea is prohibited in Kenya only between AprilAugust. Furthermore, there is no agreement on the mesh size to use for harvesting $R$. argentea: Tanzania uses a 10-mm mesh size, while Kenya and Uganda use a 5 -mm mesh size. There also is no agreement regarding minimum mesh sizes for certain fishes, such as $B$. docmak and $C$. gariepinus. Although the regulations of all three countries are similar, the penalties are different. Thus, there is an urgent need to develop, harmonize and enforce regulations governing the Lake Victoria fishery. Properly implemented monitoring, control and surveillance schemes should be linked into community-based management approaches as government enforcement has not previously worked. A system of property rights should be recognized as a necessity for implementing the management measures. A study done by the Socio-Economic Data Working Group (1999) found that beach community patrols formed to monitor their fishing grounds to keep off thieves and illegal gear were very effective.

\section{Integrated approach}

For the successful management of the lake as a whole, a holistic approach encompassing the lake and its drainage basin is important. The lake borders three countries and the effect of the watershed, which extends up to Rwanda and Burundi, is felt in Lake Victoria. Water hyacinth, which threatens the Lake Victoria ecosystem, enters the lake through the Kagera River, which has its catchment area in Rwanda and Burundi. Thus, the management of the resources of Lake Victoria requires international cooperation. In this regard, the Kenyan, Ugandan and Tanzanian governments established a regional mechanism in 1994. The Lake Victoria Fisheries Organization (LVFO), formed under the umbrella of the East African community, coordinates the management and conservation of the lake and its basin. Under the LVFO, the three riparian countries agreed to enforce legislation and regulations to protect the lake and its basin.

\section{Funds}

A big hindrance to the conservation of Lake Victoria and its fishery is the lack of adequate funds. Presently, there are no substantial funds from the riparian states' governments assigned to research and management of the lake. Rather, most of the funds are from donors. There is a need for sourcing money locally, especially from taxes. Taxes levied on the fishing industry can be used to support the research and management of fisheries resources. In search of local funds, the Kenyan Government, through the Kenya Fisheries Department, and under the auspices of the World Bank-funded Lake Victoria Environmental Management Programme, has already developed a proposal for harmonizing taxes to be levied on the fishing industry. To be known as the fish levy trust, the tax is meant to be ploughed back into the research and administration of the Lake Victoria fisheries. The continued sourcing of funds from the international community, justified on scientific, cultural and humanitarian grounds, can supplement these resources.

\section{ACKNOWLEDGEMENTS}

The authors wish to thank the Director, Kenya Marine and Fisheries Research Institute, for support. We also are grateful to all people who supported or contributed to this paper. 


\section{REFERENCES}

Abila R. (2000) The development of the Lake Victoria fishery: A boom or bane for food security? IUCN, Nairobi, Kenya. No. 8.

Abila R. O. \& Jensen E. G. (1997) Socio-economics of the Lake Victoria fisheries: From local to global markets. The fish exporting and fishmeal industries of Lake Victoria - structure, strategies and social-economic impacts in Kenya. IUCN, Nairobi, Kenya. No. 2.

Budeba Y. L. (1999) The role of Caridina Nilotica (Roux) in Lake Victoria fisheries with reference to Lates niloticus (L.). In: Report on the 4th Fisheries Data Working Group (FIDAWOG) Workshop (eds I. G. Cowx \& D. Tweddle) pp. 163-74. LVFRP, Jinja, Uganda.

Cowx I. G. (2001) Report of a Mission to East Africa, October-November, 2001, Fish Stock Assessment. LVFRP, Jinja, Uganda.

Cowx I. G., van Knaap M., van der Muhoozi L. \& Othina A. (2003) Improving fishery catch statstics for Lake Victoria. Aquat. Ecosyst. Health Manage. 6, 299-310.

Crapon de Caprona M. D. \& Fritzsch B. (1984) Interspecific fertile hybrids of haplochromine Cichlidae (Teleostei) and their possible importance for speciation. Nether. J. Zool. 4, 503-38.

Dache S. A. O. (1994) Observations on the fisheries, growth and mortality of Oreochromis niloticus (tilapia) in Nyanza Gulf of Lake Victoria. In: Recent Trends of Research in Lake Victoria Fisheries (eds E. Okemwa, E. Wakwabi \& A. Getabu) pp. 59-65. ICIPE Press, Nairobi, Kenya.

Getabu A. \& Nyaundi J. (1999) Relative abundance and distribution of fish in Kenyan waters of Lake Victoria. In: Report on the 4th Fisheries Data Working Group (FIDAWOG) Workshop (eds I. G. Cowx \& D. Tweddle) pp. 63-77. LVFRP, Jinja, Uganda.

Kudhogania A. W. \& Cordone A. J. (1974) Batho-spatial distribution pattern and biomass estimation of the major demersal fishes in Lake Victoria. Afr. J. Hydrobiol. Fish 3, 15-31.

Lung'ayia H. B. O., M’Harzi A., Tackx M., Gichuki J. \& Symoens J. J. (2000) Phytoplankton community structure and environment in the Kenyan waters of Lake Victoria. Freshwat. Biol. 43, 529-43.

Mkumbo O. C. \& Ligtvoet W. (1992) Changes in the diet of Nile perch, Lates niloticus (L.), in the Mwanza Gulf, Lake Victoria. Hydrobiologia 232, 79-84.

Muli J. R., Mavuti K. M. \& Ntiba J. M. (2000) Macro invertebrate fauna of water hyacinth in the Kenyan waters of Lake Victoria. Int. J. Ecol. Environ. Sci. 26, 281-302.

Njiru M., Okeyo-Owour J. B., Muchiri M. \& Cowx I. G.
(2004) Shift in feeding ecology of Nile tilapia, Oreochromis niloticus (L.) in Lake Victoria, Kenya. Afr. J. Ecol. 41, 1-8.

Njiru M. A. N., Othina A., Getabu D., Tweddle D. \& Cowx I. G. (2002) Is the invasion of water hyacinth, Eichhornia crassipes Solms (Mart.), a blessing to Lake Victoria fisheries? In: Management and Ecology of Lake and Reservoir Fisheries (ed. I. G. Cowx) pp. 255-63. Fishing News Books, London.

Ntiba M. J., Kudoja W. M. \& Mukasa C. T. (2001) Management issues in the Lake Victoria watershed. Lakes Reserv.: Res. Manage. 6, 211-16.

Ochumba P. B. O. \& Kibaara D. J. (1989) Observations on the blue-green algal blooms in the open waters of Lake Victoria, Kenya. Afr. J. Ecol. 27, 23-34.

Ogutu-Ohwayo R. (1990) The decline of the native fishes of lakes Victoria and Kyoga (East Africa) and the impact of introduced species, especially the Nile perch, Lates niloticus and the Nile tilapia, Oreochroms niloticus. Environ. Biol. Fish. 27, 81-96.

Okemwa E. (1981) A preliminary survey of the fisheries and limnology of Lakes Kanyaboli and Lake Sare in Western Kenya. Proceedings of the Workshop of the Kenya Marine and Fisheries Research Institute on Aquatic Resources of Kenya; 13-19 Jul 1981, Kisumu, Kenya. KMFRI, Kisumu, Kenya.

Othina A. \& Tweddle D. (1999) The status of the artisanal fishery of Lake Victoria, Kenya, with notes on improvements to the catch data collection. In: Report on the 4th Fisheries Data Working Group (FIDAWOG) Workshop (eds I. G. Cowx \& D. Tweddle) pp. 78-91. LVFRP, Jinja, Uganda.

Seehausen O., van Alphen J. J. M. \& Witte F. (1997) Cichlids diversity threatened by eutrophication that curbs sexual selection. Science 277, 1808-11.

Socio-Economic Data Working Group (1999) The survey of Lake Victoria's fishers. LVFRP, Jinja, Uganda. No. LVFRP/TECH/99/05.

Talling J. F. (1965) The photosynthetic activity of phytoplankton in East African lakes. Int. Rev. Hydrobiol. 50, 1-32.

Wanink J. H. (1998) The pelagic Rastrineobola Argentea as a crucial link in the disrupted ecosystem of Lake Victoria: Dwarfs and giants - African adventures. PhD thesis. Rijksuniversitent, Leiden, the Netherlands.

Welcomme R. L. (1967) Observations on the biology of the introduced species of Tilapia in Lake Victoria. Rev. Zool. Bot. Afr. 76, 249-79.

Witte F. \& Densen W. L. T. (1995) Fish Stocks and Fisheries of Lake Victoria. A Handbook for Field Observations. Samara Publishing, Cardigan, United Kingdom. 
Witte F., Goldshmidt T., Ligtvoet W., Oijen M. J. P. \& Wanink J. H. (1992) Species extinction and concomitant ecological changes in Lake Victoria. Neth. J. Zool. 42, 214-32.

Witte F., Goudswaard T., Katunzi E. F. B., Mkumbo O. C., Seehausen O. \& Wanink J. H. (1999) Lake Victoria's ecological changes and their relationships with the riparian societies. In: Ancient Lakes: Their Cultural and Biological Diversity (eds H. Kawanabe, G. W. Coulter \& A. C. Roosevelt) pp. 189-202. Kenobi Productions, Belgium. Worthington E. B. (1930) Observations on the temperature, hydrogen-ion concentration and other physical conditions of Victoria and Albert Nyanza. Int. Rev. Ges. Hydrobiol. Hydrogr. 24, 328-57. 